\title{
Growth and Infrastructure Development of Foreign Direct Investment in India
}

\author{
M. RamaPriya, P. Nivetha, S. Prasanth, S. Sudhamathi
}

\begin{abstract}
An outside direct venture (FDI) is an interest as an administering ownership in a business in single nation by a unit conventional in an alternate nation. Remote Direct speculation (FDI) is a most significant piece of an Indian Economic framework to build up the country. FDI plays an exceptional and developing job in worldwide business. The Foreign direct speculation viewed as the development, apparatus and hardware are the quick development and extension of the India. street and rail system is the essential piece of remote direct speculation and arrangements the market size, transportation, quality, political/financial solidness and unhindered commerce homes are the same old thing/venture atmosphere, Labor expenses and transparency. FDI assumes a fundamental job in the long haul advancement of a nation as a wellspring of capital as well as for improving appeal of the inward economy during exchange of innovation, combination framework, raising profitability and making new business openings. In India, FDI is estimated as a dynamic instrument, which aides in achieving independence in different subdivisions and in general advancement of the market. India has powerfully supported open interest in foundation as well as included private segment so as to give upgrade to the infrastructural development. Remote Direct Investment (FDI) is frequently observed as primary substances for monetary development in the creating nations like India. FDI contacts the monetary development by motivating residential venture, expanding human capital foundation and by help the innovation move in the assembly nations. The primary reason for this exploration study is to investigate the Growth and Infrastructure advancement of FDI on the financial development of India.
\end{abstract}

Keywords : FDI, Growth, Infrastructure, Business, Indian Economy.

\section{INTRODUCTION}

Outside direct speculation (FDI) plays an unprecedented and developing job in worldwide business. It can furnish a firm with new markets and consolation channels, less expensive creation offices, access to know innovation, gather, aptitudes and financing. For a swarm nation or the outside firm which gets the venture, it can give a solid stimulus to monetarily suitable advancement. Direct adventure in the structure, mechanical assembly and contraption is in uniqueness with development a collection

Revised Manuscript Received on October 15, 2019.

* Correspondence Author

M.RamaPriya, Ph.D. Research Scholar, Alagappa Institute of Management, Alagappa University, Karaikudi, India.

P.Nivetha, Ph.D. Research Scholar, Alagappa Institute of Management, Alagappa University, Karaikudi, India.

S.Prasanth, Ph.D. Research Scholar, Alagappa Institute of Management, Alagappa University, Karaikudi, India.

Dr. S. Sudhamathi, Assistant Professor, Alagappa Institute of Management, Alagappa University, Karaikudi, India theory, which is all around idea out an aberrant expense. As of late, given express development and change in comprehensive speculation design, the grouping has been expanded to incorporate the securing of enduring administration enthusiasm for an organization or try outside the contribute company's nation of origin. In that capacity, it might take a few structures, for example, an immediate obtaining of an unusual firm, production of an office, or interest in a joint endeavor or procedure union with a nearby firm with collaborator contribution of innovation. distant undying speculation might be included toward territories where the normal paces of continues are higher. This is basically the currency markets disequilibrium speculation. It infers that, for a masterminded degree of hazard, paces of profit for stuff are not balanced all inclusive by portfolio capital streams, because of wasteful aspects in protections markets, for example, thinness or be insufficient in of hole.

\section{REVIEW OF LITERATURE}

ECONOMIC GROWTH AND FDI IN INDIA :Distant Direct Investment (FDI) procured a main job in the universal economy after the Second World War. assumed investigations on FDI have prompted a superior comprehension of the monetary system and the conduct of monetary operators, both at miniaturized scale and full scale level permitting the opening of new zones of update in monetarily feasible hypothesis. To perceive outside direct reserve funds should initially comprehend the fundamental inspirations that reason a firm to contribute abroad as opposed to trade or redistribute development to national firms. Vintila Denisia (2010). The improvement of FDI in the worldwide exchange and industry scene in the course of the most recent two decades has made it a basic piece of the advancement strategy of both the created and creating countries. It goes about as a noteworthy impetus in the advancement of a nation through up-degree of innovation, administrative abilities and capacities in different segments. Outside Direct cost (FDI) is viewed as the soul of monetary improvement like never before for the creating and immature nations. It assumes a significant job in the long haul improvement of a nation as a wellspring of capital as well as for upgrading intensity of the household economy through exchange of innovation, reinforcing foundation, raising efficiency and creating new work openings. Permitting FDI demonstrates great as enhancements in production network advancements and instructive externalities to neighborhood players and focused elements that could profit buyers and providers. (Smitha Nair1 and Dr. Minimol (2015). 
The worldwide focused productive conditions no nation on the planet is independent and independence. The majority of them generally rely upon different countries somehow or another. Advance economy with surplus stores need to incorporate different countries who have minerals stores and talented works. Rising economy in plan to end up independent requires subsidize for their prudent advancement and solidification, undeveloped economy requires assets for their endurance. In this manner monetary combination through FDI assumed central job and quicken the separate economies. With developing globalization the majority of the Asian countries have respected the FDI and witness flood in its inflow. India with moderate way to deal with globalization has been discovered maverick to the FDI. Its general market potential, twitter talented workforce with mineral stores and safe marine courses alongside changed arrangement system supported its fascination as a most favored goal for remote financial specialists. (Dr S.M.Tariq Zafar 2017). said that different types of speculation procedures, outside direct venture (FDI) includes the long haul confirmation in the host nation. FDI determinants are unpredictable and multi-dimensional marvels that outcome from both large scale financial and firm procedure contemplations. The fundamental thought of the present research is to survey the observational investigations on FDI determinants so as to discover what intentions universal organizations be seeking after since the FDI strategies and country explicit business condition are legitimately influencing global partnerships' action contribution. FDI determinants so as to discover what thought processes universal companies are seeking after in such a unique business condition. The significance of these determinants consistently changes during the time spent powerful monetary condition evolvement. (Arben Sahiti1 and Skender Ahmeti 2018). There has been an ocean of progress in remote direct speculation (FDI) designs in the course of the most recent two decades. One of the critical advancements has been the creating economies and wilderness countries earning noteworthy consciousness of remote financial specialists. Districts like creating Asia have been effectively ordering a colossal portion of FDI inflows. in any case, it has been seen that FDI examples are very slanted in nature as far as segment and locale shrewd financial gatherings, for example, Asia-Pacific Economic help (APEC); Transatlantic Trade and Investment Partnership (TTIP); Brazil, Russia, India, China and South Africa (BRICS); and Regional Comprehensive Economic Partnership (RCEP). Of these, BRICS countries are perceived as the most created among the rising economies. This exploration article is an endeavor to analyze the patterns and examples of FDI streams in BRICS economies during the period from 1990 to 2015. (Soumali Bose and Bindhya kholi 2018) Distant Direct Investment (FDI) procured a main job in the universal economy after the Second World War. assumed investigations on FDI have prompted a superior comprehension of the monetary system and the conduct of monetary operators, both at miniaturized scale and full scale level permitting the opening of new zones of update in monetarily feasible hypothesis. To perceive outside direct reserve funds should initially comprehend the fundamental inspirations that reason a firm to contribute abroad as opposed to trade or redistribute development to national firms. Vintila Denisia (2010). The improvement of FDI in the worldwide exchange and industry scene in the course of the most recent two decades has made it a basic piece of the advancement strategy of both the created and creating countries. It goes about as a noteworthy impetus in the advancement of a nation through up-degree of innovation, administrative abilities and capacities in different segments. Outside Direct cost (FDI) is viewed as the soul of monetary improvement like never before for the creating and immature nations. It assumes a significant job in the long haul improvement of a nation as a wellspring of capital as well as for upgrading intensity of the household economy through exchange of innovation, reinforcing foundation, raising efficiency and creating new work openings. Permitting FDI demonstrates great as enhancements in production network advancements and instructive externalities to neighborhood players and focused elements that could profit buyers and providers. (Smitha Nair1 and Dr. Minimol (2015). The worldwide focused productive conditions no nation on the planet is independent and independence. The majority of them generally rely upon different countries somehow or another. Advance economy with surplus stores need to incorporate different countries who have minerals stores and talented works. Rising economy in plan to end up independent requires subsidize for their prudent advancement and solidification, undeveloped economy requires assets for their endurance. In this manner monetary combination through FDI assumed central job and quicken the separate economies. With developing globalization the majority of the Asian countries have respected the FDI and witness flood in its inflow. India with moderate way to deal with globalization has been discovered maverick to the FDI. Its general market potential, twitter talented workforce with mineral stores and safe marine courses alongside changed arrangement system supported its fascination as a most favored goal for remote financial specialists. (Dr S.M.Tariq Zafar 2017). said that different types of speculation procedures, outside direct venture (FDI) includes the long haul confirmation in the host nation. FDI determinants are unpredictable and multi-dimensional marvels that outcome from both large scale financial and firm procedure contemplations. The fundamental thought of the present research is to survey the observational investigations on FDI determinants so as to discover what intentions universal organizations be seeking after since the FDI strategies and country explicit business condition are legitimately influencing global partnerships' action contribution. FDI determinants so as to discover what thought processes universal companies are seeking after in such a unique business condition. The significance of these determinants consistently changes during the time spent powerful monetary condition evolvement. (Arben Sahiti1 and Skender Ahmeti 2018). There has been an ocean of progress in remote direct speculation (FDI) designs in the course of the most recent two decades. One of the critical advancements has been the creating economies and wilderness countries earning noteworthy consciousness of remote financial specialists. Districts like creating Asia have been effectively ordering a colossal portion of FDI inflows. in any case, it has been seen

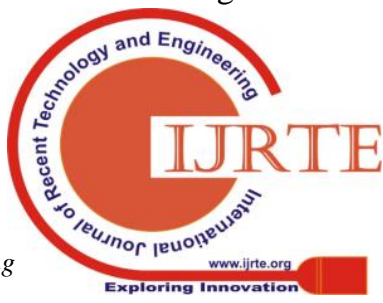


that FDI examples are very slanted in nature as far as segment and locale shrewd financial gatherings, for example, Asia-Pacific Economic help (APEC); Transatlantic Trade and Investment Partnership (TTIP); Brazil, Russia, India, China and South Africa (BRICS); and Regional Comprehensive Economic Partnership (RCEP). Of these, BRICS countries are perceived as the most created among the rising economies. This exploration article is an endeavor to analyze the patterns and examples of FDI streams in BRICS economies during the period from 1990 to 2015. (Soumali Bose and Bindhya kholi 2018).

\section{CONCEPTUAL FRAMEWORK}

\section{FDI Theories}

\section{Traditional theory}

Capital arbitrage theory - The theory states that. Direct investment flows from countries where prosperity is low to countries where profitability is high. It means therefore that capital is mobile both nationally and internationally. But sometimes implication is that countries with abundant capital should export and countries among less capital should import. If there was a link between the long-term interest rate and return on capital, portfolio investment and FDI should be moving in the same direction. International trade theory-the country will specialise in production of, and export those commodities which make demanding use of the country's relatively rich factor.

\section{Modern theory}

Product-cycle theory - New products appear first in the most advanced nation in respond to demand conditions. The budding product stage is described by standardization of the product, increased economy of scale, towering demand and low price .The standardised product stage is reached when the service is sold entirely on price basis. The theory explain that why the cross-border communication of transitional products are organised by hierarchies rather than determined by market forces. The presumption of appropriability. The theory explains why there is a strong presence of high-technology industries among MNCs

\section{The electric theory of FDI}

The theory tries to offer a general framework for determining the extent and pattern of both foreign-owned production undertaken by a country's own enterprises, and that of domestic production owned or controlled by foreign firm. Dunning and Lundan(2008).

\section{RESEARCH OBJECTIVE AND METHODOLOGY}

\section{Objective of study}

The core objective of the study is to examine and weigh up the recent amendment of FDI inflows and its overall nation's economic growth and infrastructure development. In addition, for better future and overall growth and development of nation's economy will suggest rational and strategic approach to increase FDI inflow which can leverage nation's GDP and long term growth.
The present study is exclusively based on secondary data and is carried out to examine and evaluate the growth and infrastructure development of FDI on Nations economic growth. For the rationale of study secondary data and reports are been used, which are collected from available reports of nations premier economical and commercial institutions, magazines, RBI annual report, DIPP reports and notifications, research articles and financial institutions websites. After judicious appraisal of FDI and strategic relationship between FDI and profitable growth suggestions and recommendations are made. The outcome of the study depends on the preferred period by the researchers which may perhaps differ from further investigation.

\section{ANALYTICAL TOOLS}

To analyze the collected data the following geometric tools were used.

To work out the trend analyses the following formula is used: a.) Trend Analysis i.e. $\hat{y}=a+b x ; a=y-a x i s$ intercept; $b=$ slope of the regression line; $\mathrm{x}=$ independent variable (which is time in this case).

b.) Annual Growth rate is worked out by using the following formula:

$\mathrm{AGR}=(\mathrm{X} 2-\mathrm{X} 1) / \mathrm{X} 1$

where $\mathrm{X} 1=$ first value of variable $\mathrm{X} ; \mathrm{X} 2=$ second value of variable $\mathrm{X}$.

\section{DATA ANALYSIS AND INTERPRETATION} ANNUAL GROWTH RATE \& TREND ANALYSIS

MUMBAI

\begin{tabular}{|l|l|l|l|l|}
\hline S.NO & YEAR & $\begin{array}{l}\text { AMOUN } \\
\text { T }\end{array}$ & $\begin{array}{l}\text { GROWTH } \\
\text { RATE }\end{array}$ & $\begin{array}{l}\text { TREND } \\
\text { ANALYSIS }\end{array}$ \\
\hline $\mathbf{1}$ & $2016-17$ & 131,980 & & 151379 \\
\hline $\mathbf{2}$ & $2017-18$ & 86,244 & -34.6537 & 125396 \\
\hline $\mathbf{3}$ & $2018-19$ & 80,013 & -7.22485 & 99413 \\
\hline
\end{tabular}

\begin{tabular}{|l|l|l|l|l|l|}
\hline Model & $\begin{array}{l}\text { Sum of } \\
\text { Squares }\end{array}$ & df & $\begin{array}{l}\text { Mean } \\
\text { Square }\end{array}$ & F & Sig. \\
\hline Regression & 1.3509 & 1 & 1.3509 & 5.191 & $.263 \mathrm{~b}$ \\
$\mathbf{1}$ & 2.608 & 1 & 2.608 & & \\
Residual & 1.6109 & 2 & & & \\
Total & & & & & \\
\hline
\end{tabular}

\section{INTREPRETATION}

From the table 5.1 it reveals that the all Sector of FDI inflows India in the years from 2016-2019. In the years total quantity of all sector FDI inflows are Rs. 298237 crores. The highest amount of all sector FDI inflows are Rs.131980 crores obtained for March 2019. The annual growth rate of FDI inflows in 2017-18 (-34.65) and 2018-19 FDI inflows (-7.22). the trend for FDI inflows 2016-17 (151379) and 2017-18 FDI Inflows in (125396) and FDI inflows in 2018-19 (99413).

\section{Methodology}


The ANOVA results in Table 5.1 indicate that the value of F calculated Value was 5.191 and the significance was 2.63. The tabulated $f$ value at 1 numerator degrees of freedom and 1 denominator degrees of freedom was 2 . Since the value of premeditated $\mathrm{f}$ was greater than the f critical (5.191> 4.06), the regression model was thus significant.

\section{NEWDELHI}

\begin{tabular}{|l|l|l|l|l|}
\hline $\begin{array}{l}\text { S. } \\
\text { NO }\end{array}$ & YEAR & $\begin{array}{l}\text { AMOUN } \\
\text { T }\end{array}$ & $\begin{array}{l}\text { GROWT } \\
\text { H RATE }\end{array}$ & $\begin{array}{l}\text { TREND } \\
\text { ANALYSIS }\end{array}$ \\
\hline $\mathbf{1}$ & $2016-17$ & 39,482 & - & 22108 \\
\hline $\mathbf{2}$ & $2017-18$ & 49,366 & 25.03419 & 37609 \\
\hline $\mathbf{3}$ & $2018-19$ & 70,485 & 42.78046 & 53110 \\
\hline
\end{tabular}

ANOVA ${ }^{a}$

\begin{tabular}{|r|r|r|l|l|l|}
\hline \multicolumn{1}{|c|}{ Model } & $\begin{array}{c}\text { Sum of } \\
\text { Squares }\end{array}$ & df & $\begin{array}{c}\text { Mean } \\
\text { Square }\end{array}$ & F & Sig. \\
\hline Regression & 4.8108 & 1 & 4.8108 & 22.845 & $.131^{\mathrm{b}}$ \\
$\mathbf{1}$ & 21037538 & 1 & 21037538 & & \\
Residual & 5.0208 & 2 & & & \\
Total & & & & & \\
& & & & & \\
\hline
\end{tabular}

\section{INTREPRETATION}

From the table 5.2 it is reveals that the all Sector of FDI inflows India in the years from 2016-2019. In the years total sum of all sector FDI inflows are Rs. 159333 crores. The highest amount of all sector FDI inflows are Rs. 70485 crores obtained for March 2019. The twelve-monthly growth rate of FDI inflows in 2017-18 (25.03) and 2018-19 FDI inflows (42.78). the trend for FDI inflows 2016-17 (22108) and 2017-18 FDI Inflows in (37609) and FDI inflows in 2018-19 (5311).

The ANOVA results in Table 5.2 indicate that the value of $F$ calculated Value was 22.845 and the significance was .131. The tabulated $\mathrm{f}$ value at 1 numerator degrees of freedom and 1 denominator degrees of freedom was 2 . Since the value of calculated $f$ was greater than the f critical $(22.845>8.52)$, the decay model was thus significant.

BANGALORE

\begin{tabular}{|l|l|l|l|l|}
\hline $\begin{array}{l}\text { S.N } \\
\mathbf{O}\end{array}$ & YEAR & $\begin{array}{l}\text { AMOUN } \\
\text { T }\end{array}$ & $\begin{array}{l}\text { GROWT } \\
\text { H RATE }\end{array}$ & $\begin{array}{l}\text { TREND } \\
\text { ANALYSIS }\end{array}$ \\
\hline $\mathbf{1}$ & $\begin{array}{l}2016-1 \\
7\end{array}$ & 14,300 & - & 6202 \\
\hline $\mathbf{2}$ & $\begin{array}{l}2017-1 \\
8\end{array}$ & 55,334 & 286.951 & 22533 \\
\hline $\mathbf{3}$ & $\begin{array}{l}2018-1 \\
9\end{array}$ & 46,963 & -15.1281 & 38864 \\
\hline
\end{tabular}

ANOVAa

\begin{tabular}{|r|c|c|c|c|c|}
\hline Model & $\begin{array}{c}\text { Sum of } \\
\text { Squares }\end{array}$ & df & $\begin{array}{c}\text { Mean } \\
\text { Square }\end{array}$ & F & Sig. \\
\hline Regression & 5.3308 & 1 & 5.3308 & 1.311 & $.457^{\mathrm{b}}$ \\
$\mathbf{1}$ & 4.0708 & 1 & 4.0708 & & \\
Residual & 9.408 & 2 & & & \\
Total & & & & & \\
\hline
\end{tabular}

INTERPRETATION
From the table 5.3 it is reveals that the all Sector FDI inflows India in the years from 2016-2019. In the years total sum of sectors of FDI inflows are Rs. 116597crores. The highest amount of all sector FDI inflows are Rs.55334 crores obtained for March 2018. The twelve-monthly growth rate of FDI inflows in 2017-18 (286.95) and 2018-19 FDI inflows (-15.12). the trend for FDI inflows 2016-17 (6202) and 2017-18 FDI Inflows in (22533) and FDI inflows in 2018-19 (38864).

The ANOVA results in Table 5.3 indicate that the value of $F$ calculated Value was 1.311 and the significance was .457 . The tabulated f value at 1 numerator degrees of freedom and 1 denominator degrees of freedom was 2 . Since the value of calculated $\mathrm{f}$ was less than the $\mathrm{f}$ critical $(1.311<39.86)$, the regression model was not significant.

\section{CHENNAI}

\begin{tabular}{|l|l|l|l|l|}
\hline $\begin{array}{l}\text { S.N } \\
\text { O }\end{array}$ & YEAR & $\begin{array}{l}\text { AMOUN } \\
\text { T }\end{array}$ & $\begin{array}{l}\text { GROWT } \\
\text { H RATE }\end{array}$ & $\begin{array}{l}\text { TREND } \\
\text { ANALYSIS }\end{array}$ \\
\hline $\mathbf{1}$ & $2016-17$ & 14,830 & - & 15115 \\
\hline $\mathbf{2}$ & $2017-18$ & 22,354 & 50.735 & 16782 \\
\hline $\mathbf{3}$ & $2018-19$ & 18,164 & -18.7438 & 18449 \\
\hline
\end{tabular}

ANOVAa

\begin{tabular}{|r|l|l|l|l|l|}
\hline Model & $\begin{array}{l}\text { Sum of } \\
\text { Squares }\end{array}$ & df & $\begin{array}{l}\text { Mean } \\
\text { Square }\end{array}$ & F & Sig. \\
\hline Regression & 49920032 & 1 & 49920032 & 4.333 & $.285^{\mathrm{b}}$ \\
$\mathbf{1}$ & 11520433 & 1 & 11520433 & & \\
$\begin{array}{r}\text { Residual } \\
\text { Total }\end{array}$ & 61440465 & 2 & & & \\
\hline
\end{tabular}

\section{INTREPRETATION}

From the table 5.4 it is reveals that the all Sector FDI inflows India in the years from 2016-2019. In the years total amount of all sector FDI inflows are Rs.55348 crores. The highest amount of all sector FDI inflows are Rs.22354 crores obtained for March 2018. The annual growth rate of FDI inflows in 2017-18 (50.73) and 2018-19 FDI inflows $(-18.74)$. the trend for FDI inflows 2016-17 (15115) and 2017-18 FDI Inflows in (16782) and FDI inflows in 2018-19 (18449).

The ANOVA results in Table 5.4 indicate that the value of $F$ calculated Value was 4.333 and the significance was .285. The tabulated $f$ value at 1 numerator degrees of freedom and 1 denominator degrees of freedom was 2 . Since the value of calculated $f$ was greater than the f critical $(4.333>4.16)$, the regression model was thus significant.

\begin{tabular}{|l|l|l|l|c|}
\hline $\begin{array}{l}\text { S. } \\
\text { NO }\end{array}$ & YEAR & $\begin{array}{l}\text { AMOUN } \\
\text { T }\end{array}$ & $\begin{array}{l}\text { GROWT } \\
\text { H RATE }\end{array}$ & $\begin{array}{l}\text { TREND } \\
\text { ANALYSIS }\end{array}$ \\
\hline $\mathbf{1}$ & $2016-17$ & 22,610 & - & 26220 \\
\hline $\mathbf{2}$ & $2017-18$ & 13,457 & -40.4821 & 21224 \\
\hline $\mathbf{3}$ & $2018-19$ & 12,618 & -6.23467 & 16228 \\
\hline
\end{tabular}




\begin{tabular}{|c|c|c|c|c|c|}
\hline \multicolumn{6}{|c|}{ ANOVA $^{a}$} \\
\hline Model & $\begin{array}{l}\text { Sum of } \\
\text { Squares }\end{array}$ & df & $\begin{array}{l}\text { Mean } \\
\text { Square }\end{array}$ & $\mathbf{F}$ & Sig. \\
\hline Regression & 5557778 & 1 & 5557778 & 0.243 & $.708^{b}$ \\
\hline 1 & 22869633 & 1 & 22869633 & & \\
\hline $\begin{array}{r}\text { Residual } \\
\text { Total }\end{array}$ & 28427411 & 2 & & & \\
\hline
\end{tabular}

\section{INTREPRETATION}

From the table 5.5 it is reveals that the all Sector FDI inflows India in the years from 2016-2019. In the years total amount of all sector FDI inflows are Rs. 48685crores. The highest amount of all sector FDI inflows are Rs.22610 crores obtained for March 2019. The annual growth rate of FDI inflows in 2017-18 (-40.48) and 2018-19 FDI inflows (-6.2). the trend for FDI inflows 2016-17 (22610) and 2017-18 FDI Inflows in (13457) and FDI inflows in 2018-19 (12618).

The ANOVA results in Table 5.5 indicate that the value of $F$ calculated Value was 0.243 and the significance was 708 . The tabulated $\mathrm{f}$ value at 1 numerator degrees of freedom and 1 denominator degrees of freedom was 2 . Since the value of calculated $f$ was less than the $f$ critical $(0.243<39.86)$, the regression model was not significant.

\section{CONCLUSION}

The study concluded that economic growth has an influence on foreign direct investments. Policies which promote economic growth and development of infrastructure should be given sufficient attention in order to attract foreign direct investment. This is due to the fact that positive economic growth attracts FDI. It is important to note that India has low levels of foreign direct investments hence it needs to develop its immediate business surroundings through improving on its administrative procedures and legal systems so as to improve economic growth. These factors would lead to higher levels of FDI being channelled into the country. Foreign direct investment ought to be channelled into profitable and self sustainable projects for which they are targeted. India has been faced with mismanagement of funds and in this regard, appropriate bodies and authorities should vigilantly perform their tasks and make follow ups on those who misappropriate project money. The study however noted that improve infrastructure of Indian economic growth thus we need to encouraging the foreign direct investments. The central bank of India should form and implement adequate policies to ensure that the local currency remains valuable despite the tough economic times. A depreciating currency would lead to low returns on investments due to high production costs thus discouraging investments both local and international.

\section{REFERENCES}

1. Dr S.M.Tariq Zafar \&Waleed Hmedat (2017) An analytical study on foreign direct investment (FDI) and its relative impact on Indian economy, International journal of core engineering and Management vol 3 Issue 12 ISSN : $2348-9510$

2. Arben Sahiti \& Skender Ahmeti (2018) A Review of Empirical Studies on Fdi Determinants, Baltic Journal of Real Estate Economics and Construction Management ISSN: 2255-9671 (online) 2018, 6, 37-47 doi: $10.1515 /$ bjreecm-2018-0003

3. Soumali Bose \& Bindhya kholi (2018) Study of FDI Trends and Patterns in BRICS Economies during the Period 1990-2015, Emerging Economy Studies sage Publications 4(1) 78-101
4. Hamza, F. M. (2017). Impact of Foreign Direct Investment (Fdi) on the Growth. Pyrex Journal of Business and Finance Management Research , 3 (2), 86-97.

5. Khatoon, D. (2016). A STUDY OF GROWTH OF FOREIGN DIRECT INVESTMENT IN DIFFERENT SECTORS OF INDIANECONOMY-A DESCRIPTIVE AND ANALYTICAL STUDY. InternationalJournalofBusinessand AdministrationResearch Review , 1 (1), 58.

6. Nair1, S. B. ((2017)). Impact of FDI on Indian Economy - An Analytical International Journal of Science and Research , 6 (3), 1486-1491.

7. Zafar, D. S. (2017). AN ANALYTICAL STUDY ON FOREIGN DIRECT INVESTMENT (FDI) AND ITS RELATIVE IMPACT ON INDIAN ECONOMY. International Journal Of Core Engineering \& Management, Volume-3 (Issue-12), 1-18. 